University of Nebraska - Lincoln

DigitalCommons@University of Nebraska - Lincoln

Agronomy \& Horticulture -- Faculty Publications

Agronomy and Horticulture Department

1961

\title{
Activities of Acid Phosphatase, Peroxidase, and Polyphenolase in Etiolated Shoots from Control and Irradiated Maize Seeds
}

Francis A. Haskins

University of Nebraska-Lincoln, fhaskins@neb.rr.com

S. C. Downs

University of Nebraska-Lincoln

Follow this and additional works at: https://digitalcommons.unl.edu/agronomyfacpub

Part of the Plant Sciences Commons

Haskins, Francis A. and Downs, S. C., "Activities of Acid Phosphatase, Peroxidase, and Polyphenolase in Etiolated Shoots from Control and Irradiated Maize Seeds" (1961). Agronomy \& Horticulture -- Faculty Publications. 271.

https://digitalcommons.unl.edu/agronomyfacpub/271

This Article is brought to you for free and open access by the Agronomy and Horticulture Department at DigitalCommons@University of Nebraska - Lincoln. It has been accepted for inclusion in Agronomy \& Horticulture -Faculty Publications by an authorized administrator of DigitalCommons@University of Nebraska - Lincoln. 


\title{
Activities of Acid Phosphatase, Peroxidase, and Polyphenolase in Etiolated Shoots from Control and Irradiated Maize Seeds ${ }^{1}$
}

\author{
F. A. Haskins and S. C. Downs ${ }^{2}$
}

SYNOPSIS. Evidence is presented that enzymatic differences exist between etiolated shoots from appropriately irradiated maize seeds and shoots from control seeds. Differences in specific activities of acid phosphatase and peroxidase became apparent only when individual portions (first internode, coleoptile, and unexpanded foliage leaves) of the shoot were considered. Contributions of the three shoot portions to total activities of acid phosphatase, peroxidase, and polyphenolase also were studied, and irradiation-induced differences in the patterns of contribution were noted.

$I^{\mathrm{N}}$

N A previous report from this laboratory (3), differences in the activities of acid phosphatase, peroxidase, and polyphenolase in preparations of green seedlings grown from control and irradiated seeds of maize were described. Also in that report, reference was made to the contrasting fact that work with etiolated shoots failed to

\footnotetext{
${ }^{1}$ Research was conducted under Contract No. AT (11-1)-393, United States Atomic Energy Commission. Published with the approval of the Director as paper No. 1049, Journal Series, Nebraska Agricultural Experiment Station.

${ }^{2}$ Professor and Assistant in Agronomy, respectively, Agronomy Department, University of Nebraska, Lincoln. Present address of the junior author: L. S. Geological Survey, Lincoln, Nebraska. Acknowledgment is made to Warren W. Saths, Foundation Seed Division, University of Nebraska for supplying the L289 $\times$ I205 seed.
}

disclose large or consistent irradiation-induced differences in these three enzymatic activities. Etiolated shoots of maize consist of three major portions: the first internode of the stem, the coleoptile, and the unexpanded foliage leaves and shoot apex within the coleoptile. Grcen seedlings as used in the foregoing experiments represented the development of only the last named portion of the shoot, and did not include tissues of the first internode or coleoptile. The present report deals with studies designed to determine whether differences exist in certain enzymatic properties of the three shoot portions, and whether, through the use of preparations of the separate portions, patterns of enzymatic activity might be detected which would correspond to patterns observed in green seedling preparations.

\section{MATERIALS AND METHODS}

Seeds of the single-cross maize hybrid, L289 $\times$ I205, were used in these studies. X-ray and thermal neutron treatments were administered under the supervision of Seymour Shapiro at the Brook. haven National Laboratory. Irradiation procedures were similar to those which have been described elsewhere (3)

Seeds to be germinated were immersed for 5 min. in a $1 \%$ sodium hypochlorite solution, rinsed several times in distilled water, and planted in sterile vermiculite in enameled pans. Fol. lowing saturation of the vermiculite with distilled water, the seeds 
were allowed to germinate in a dark chamber at $24^{\circ}$ C. A germination period of 6 days was used for all material.

Following the germination period, shoots were separated from the remainder of the seedling at the scutellar node and their lengths and weights were measured. A sample was set aside for use in the "entire shoot" preparation, and the remaining shoots were dissected into the three major portions, first internode, coleoptile, and unexpanded foliage leaves and shoot apex (for convenience, the last portion will be referred to as "leaves"). Fresh weights of the portions were recorded.

Procedures used in making enzyme preparations and in assaying acid phosphatase, peroxidase, and polyphenolase activities and protein nitrogen content have been described earlier (2). Dilutions were such that in all cases $1 \mathrm{ml}$. of crude enzyme preparation corresponded to $0.1 \mathrm{~g}$. of fresh tissue. For peroxidase and polyphenolase assays, volumes indicated in the published procedures were modified slightly to permit use of the Bausch and Lomb Spectronic 20 Colorimeter. Three series of assays were completed, each series involving samples from six irradiated lots and one control tot of seeds. Duplicate determinations of acid phosphatase, peroxidase, and polyphenolase activities and protein nitrogen were made for each enzyme preparation in each series. Analysis of variance tech. niques and other statistical procedures used in analyzing the results have been presented by Snedecor (5)

\section{RESULTS AND DISCUSSION}

It is apparent from the values presented in table 1 that in comparison with etiolated shoots from control seeds, shoots from appropriately irradiated seeds were markedly reduced in length and weight. The reason for the unexpectedly great effect of the lowest neutron dosage is not known. Patterns of fresh weight distribution in the etiolated shoots are shown in table 2. The data indicate that with increased dosage of irradiation, the percentage of fresh weight contributed by the first internode decreased, while the percentage contributed by the coleoptile increased and that contributed by the leaves remained relatively unchanged.

Data on nitrogen contents and specific enzyme activities are presented in table 3 . Within any of the four types of preparation, protein nitrogen contents did not differ significantly with treatment. Results of acid phosphatase and polyphenolase assays of entire shoot preparations agreed with earlier observations (3) that such preparations do not

Table 1-Lengths and fresh weights of 6-day etiolated shoots from control and irradiated maize seeds. Measurements are based on all shoots used in making enzyme preparations.

\begin{tabular}{lccc}
\hline \multicolumn{1}{c}{ Treatment } & $\begin{array}{c}\text { Number } \\
\text { of shoots }\end{array}$ & $\begin{array}{c}\text { Length, mm. } \\
\text { mean } \pm \mathrm{SE}\end{array}$ & $\begin{array}{c}\text { Fresh weight, } \\
\text { g. mean }\end{array}$ \\
\hline Control & 38 & $127 \pm 8.0$ & 0.39 \\
$15,000 \mathrm{rX}$-ray & 41 & $104 \pm 6.2$ & 0.32 \\
$30,000 \mathrm{rX}$-ray & 46 & $75 \pm 3.1$ & 0.23 \\
$60,000 \mathrm{r}$ X-ray & 57 & $41 \pm 1.4$ & 0.12 \\
$1.65 \times 10^{13} \mathrm{Nth}_{\mathrm{th}} / \mathrm{cm}^{2}$ & 40 & $78 \pm 4.2$ & 0.24 \\
$3.09 \times 10^{13} \mathrm{Nth} / \mathrm{cm}^{2}$ & 46 & $83 \pm 2.8$ & 0.26 \\
$6.21 \times 10^{13} \mathrm{~N}_{\text {th }} / \mathrm{cm}^{2}$ & 62 & $50 \pm 1.3$ & 0.14 \\
\hline
\end{tabular}

Table 2-Distribution of fresh weight in etiolated shoots from control and irradiated maize seeds.

\begin{tabular}{|c|c|c|c|}
\hline \multirow[t]{2}{*}{ Treatment } & \multicolumn{3}{|c|}{ Percentage of fresh weight contributed by } \\
\hline & First internode & Coleoptile & Leaves \\
\hline Control & 60 & 266 & 14 \\
\hline $\begin{array}{l}15,000 \text { r X-ray } \\
30,000 \text { r X-ray } \\
60,000 \text { r X-ray }\end{array}$ & $\begin{array}{l}38 \\
54 \\
37\end{array}$ & $\begin{array}{l}28 \\
33 \\
46\end{array}$ & $\begin{array}{l}14 \\
12 \\
17\end{array}$ \\
\hline $\begin{array}{l}\text { 1. fi5 } \times 10^{13} \mathrm{~N}_{\mathrm{th}} / \mathrm{cm}_{.}{ }^{2} \\
3.09 \times 10^{13} \mathrm{~N}_{\mathrm{th}} / \mathrm{cm}_{.}{ }^{2} \\
6.21 \times 10^{13} \mathrm{~N}_{\mathrm{th}} / \mathrm{cms}^{?}\end{array}$ & $\begin{array}{l}62 \\
50 \\
40\end{array}$ & $\begin{array}{l}29 \\
36 \\
45\end{array}$ & $\begin{array}{l}10 \\
14 \\
15\end{array}$ \\
\hline $\begin{array}{l}\text { Standard error of a } \\
\text { treatment mean }\end{array}$ & 2.5 & 1.9 & 1.4 \\
\hline Level of significance* & .01 & .01 & NS \\
\hline
\end{tabular}

the .05 and .01 levels of probability. NS indicites lacts of significanet.

display large or consistent treatment-induced differences with respect to these enzymes. Treatment differences in acid phosphatase and polyphenolase activities of first internode and coleoptile preparations were similarly insignificant. Peroxidase activity of entire shoot, first internode, and coleoptile preparations appeared to increase somewhat with dosage of irradiation, but statistical analysis of the data revealed that within each of the three types of preparation, treatment means did not differ at the 0.05 level of probability. Leaf preparations, in contrast to the other three types of preparation, displayed differences in acid phosphatase and peroxidase activities which exceeded the values required for significance at the 0.01 level of probability. Differences in polyphenolase activities of leaf preparations, however, were not significant at the 0.05 level.

On the basis of the foregoing observations, it is reasonable to conclude that previously-described effects of irradiation on the activities of peroxidase and phosphatase in green seedlings (3) represent a continuation of effects which are detectable in that portion of the shoot which is destined to develop into the above-ground portion of the green seedling. With respect to polyphenolase activity, however, neither preparations of the entire etiolated shoot nor of any portion thereof gave an accurate indication of the irradiation effects which were manifested in the green seedling stage. Apparently these effects on polyphenolase activity were dependent upon metabolic processes which occurred in the green seedling but not in the etiolated shoot.

Table 3-Specific activities of 3 enzymes in preparations of etiolated shoots from control and irradiated seeds of maize, and of the 3 principal portions of such shoots. Figures are mean values for 3 series of experiments except where otherwise indicated.

\begin{tabular}{|c|c|c|c|c|c|}
\hline \multirow[t]{2}{*}{ Portion } & \multirow[t]{2}{*}{ Treatmont } & \multirow{2}{*}{$\begin{array}{l}\mathrm{N} \text { content } \\
\text { of } \text { yrep. } \\
\text { (mg. } / \mathrm{ml} \text {.) }\end{array}$} & \multicolumn{3}{|c|}{ Specific activity* } \\
\hline & & & $\begin{array}{c}\text { Acid } \\
\text { phos- } \\
\text { phatase }\end{array}$ & $\begin{array}{l}\text { Per- } \\
\text { oxi- } \\
\text { dase }\end{array}$ & $\begin{array}{l}\text { Poly- } \\
\text { pheno- } \\
\text { lase }\end{array}$ \\
\hline \multirow{3}{*}{$\begin{array}{l}\text { Entire } \\
\text { shoot }\end{array}$} & Control. & 0.074 & 2.45 & 79 & 1.53 \\
\hline & $\begin{array}{l}15,000 \times X-1 a y \\
30,000 \times X-r a y \\
60,000 \times \text { r ray }\end{array}$ & $\begin{array}{l}0.075 \\
0.093 \\
0.088\end{array}$ & $\begin{array}{l}2.56 \\
2.41 \\
2.67\end{array}$ & $\begin{array}{r}77 \\
101 \\
109\end{array}$ & $\begin{array}{l}2.34 \\
1.60 \\
2.26\end{array}$ \\
\hline & $\begin{array}{l}1.65 \times 10^{13} \mathrm{~N}_{\mathrm{th}} / \mathrm{cm}^{2}{ }^{2} \\
3.09 \times 10^{13} \mathrm{Nth}^{2} / \mathrm{cm}^{2} \\
6.21 \times 10^{13} \mathrm{~N}_{\mathrm{th}} / \mathrm{cm}^{2}\end{array}$ & $\begin{array}{l}0.085 \\
0.089 \\
0.090\end{array}$ & $\begin{array}{l}2.66 \\
2.34 \\
2.91\end{array}$ & $\begin{array}{r}85 \\
77 \\
116\end{array}$ & $\begin{array}{l}2.54 \\
\text { 1. } 54 \\
1.82\end{array}$ \\
\hline \multirow{3}{*}{$\begin{array}{l}\text { First } \\
\text { internode }\end{array}$} & Control & 0.059 & 2.72 & 104 & 0.50 \\
\hline & $\begin{array}{l}15,000 \times \text { X-ray } \\
30,000 \times \text { X-ray } \\
60,000 \times \text { X-ray }\end{array}$ & $\begin{array}{l}0.052 \\
0.069 \\
0.078\end{array}$ & $\begin{array}{l}3.15 \\
2.91 \\
2.96\end{array}$ & $\begin{array}{r}94 \\
127 \\
172\end{array}$ & $\begin{array}{l}0.49 \\
0.41 \\
0.47\end{array}$ \\
\hline & $\begin{array}{l}1.65 \times 10^{13} \mathrm{~N} \mathrm{th} / \mathrm{cm}_{.}^{2} \\
3.09 \times 10^{13} \mathrm{~N}_{\mathrm{th}} / \mathrm{cm}^{2} \\
6.21 \times 10^{13} \mathrm{~N}_{\mathrm{th}} / \mathrm{cm}^{2}\end{array}$ & $\begin{array}{l}0.0881 \\
0.073 \\
0.077\end{array}$ & $\begin{array}{l}2.094 \\
2.95 \\
3.12\end{array}$ & $\begin{array}{l}82 \dagger \\
130 \\
150\end{array}$ & $\begin{array}{l}0.29 \dagger \\
0.41 \\
0.4 .3\end{array}$ \\
\hline \multirow[t]{3}{*}{ Coleoptile } & Control & 0.057 & 3.11 & 60 & 0.34 \\
\hline & $\begin{array}{l}15,000 \times X-r a y \\
30,000 \times \text { X-riy } \\
60,000 \times \text { X ray }\end{array}$ & $\begin{array}{l}0.070 \\
0.058 \\
0.067\end{array}$ & $\begin{array}{l}3.03 \\
4.07 \\
2.93\end{array}$ & $\begin{array}{l}44 \\
5 \% \\
98\end{array}$ & $\begin{array}{l}0.48 \\
0.82 \\
0.32\end{array}$ \\
\hline & $\begin{array}{l}1.65 \times 10^{13} \mathrm{Nhth}^{2} / \mathrm{cm}^{2} \\
3.09 \times 10^{13} \mathrm{~N}_{\mathrm{hh}} / \mathrm{cm}^{2} \\
6.21 \times 10^{13} \mathrm{~N}_{\mathrm{th}} / \mathrm{cm}^{2}\end{array}$ & $\begin{array}{l}0.063 \dagger \\
0.056 \\
0.059\end{array}$ & $\begin{array}{l}2.857 \\
2.67 \\
3.39\end{array}$ & $\begin{array}{l}67+ \\
61 \\
78\end{array}$ & $\begin{array}{l}0.337 \\
0.534 \\
0.59\end{array}$ \\
\hline \multirow[t]{3}{*}{ Leaves } & Control & 0.145 & 1.13 & 20 & 6. 8.85 \\
\hline & $\begin{array}{l}15,000 \times x-r a y \\
30,000 \times X-r a y \\
60,000 \times X-r a y\end{array}$ & $\begin{array}{l}0.128 \\
0.119 \\
0.101\end{array}$ & $\begin{array}{l}1.22 \\
1.45 \\
2.25\end{array}$ & $\begin{array}{r}25 \\
23 \\
113\end{array}$ & $\begin{array}{l}7.48 \\
6.64 .1 \\
1.38\end{array}$ \\
\hline & $\begin{array}{l}1.65 \times 10^{13} \mathrm{Nth} / \mathrm{cm}^{2} \\
3.09 \times 10^{13} \mathrm{Nht} / \mathrm{cm}^{2} \\
6.21 \times 10^{13} \mathrm{Nth} / \mathrm{cm}^{2}\end{array}$ & $\begin{array}{l}0.135 \dagger \\
0.114 \\
0.101\end{array}$ & $\begin{array}{l}1.239 \\
1.32 \\
2.17\end{array}$ & $\begin{array}{r}25 t \\
49 \\
111\end{array}$ & $\begin{array}{l}7.31+ \\
7.12 \\
4.12\end{array}$ \\
\hline \multicolumn{6}{|c|}{ 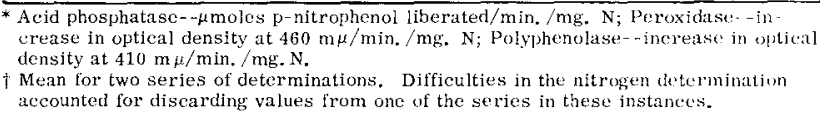 } \\
\hline \multicolumn{6}{|c|}{$\begin{array}{l}\text { Note: As indicated by the } \mathrm{F} \text { test, differences among treatment means are signifi- } \\
\text { cant at the. } 01 \text { level of probability for acid phosphatase and peroxidase activties in } \\
\text { preparations of leaves, Values for standard error of a treatment mean are } 0.210 \\
\text { and } 11.4 \text { for acid phosphatase and peroxidase activities, respectively, in leat } \\
\text { preparation. }\end{array}$} \\
\hline
\end{tabular}


Table 4-Lengths and fresh weights of etiolated maize shoots of various ages used in making enzyme preparations, and distribution of fresh weight in the shoots.

\begin{tabular}{|c|c|c|c|c|c|c|}
\hline \multirow[t]{2}{*}{$\begin{array}{l}\text { Afre, } \\
\text { days }\end{array}$} & \multirow{2}{*}{$\begin{array}{c}\text { Number } \\
\text { of } \\
\text { shoots }\end{array}$} & \multirow{2}{*}{$\begin{array}{c}\text { Length, } \\
\text { mm. } \\
\text { mean } \pm \mathrm{SE}\end{array}$} & \multirow{2}{*}{$\begin{array}{l}\text { Fresh } \\
\text { weight, } \\
\text { g. (mcan) }\end{array}$} & \multicolumn{3}{|c|}{$\begin{array}{l}\text { Pereentage of tresh } \\
\text { weight contributed by }\end{array}$} \\
\hline & & & & First internode: & Coleoptile & Leaves \\
\hline 3 & 32 & $34+2.1$ & 0.09 & 66 & 25 & 9 \\
\hline 5 & 14 & $103+13,5$ & 0.31 & 65 & 24 & 11 \\
\hline 6 & 16 & $110 \pm 14.6$ & 0.36 & 54 & 30 & 16 \\
\hline
\end{tabular}

Further examination of the data in table 3 indicates that with respect to acid phosphatase, specific activities of preparations of the three shoot portions were of the same order of magnitude. This statement applies also to peroxidase. Polyphenolase, however, presents a strikingly different situation. For this enzyme, specific activities of leaf preparations were approximately ten times as high as those of first internode and coleoptile preparations.

By themselves, of course, specific activity values for the enzymes do not fully reveal the contribution of each shoot portion toward the total activity of the shoot. Such contribution may be calculated, however, by taking into account the protein nitrogen contents of the enzyme preparations and the fresh weight contributions of the portions, in addition to the specific activities. Calculations of this nature provide the basis for the following statements: (a) For all treatments, percentages of acid phosphatase activity contributed by the three shoot portions corresponded closely to percentages of fresh weight contributed. (b) With respect to peroxidase activity, the percentage attributable to the first internode was consistently greater than the contribution of this portion to the fresh weight of the shoot, and the contribution of the coleoptile was consistently less than its fresh weight contribution. (c) The percentage of polyphenolase activity contributed by the leaves was invariably much greater than the percentage of fresh weight accounted for by this portion, and the first internode and coleoptile accounted for considerably less polyphenolase activity than their respective weight contributions. With increasing dosage of irradiation there was a tendency for the leaves to contribute a smaller percentage of the total polyphenolase activity, while first internode and coleoptile portions tended to gain in percentage of polyphenolase contributed. Correlation coefficients for the relationships between fresh weight contribution and contribution of acid phosphatase, peroxidase, and polyphenolase activities were $0.954,0.873$, and -0.751 , respectively. All three values exceed that required for significance at the 0.01 level of probability.

For purposes of comparison with results on irradiated material, determinations were made of the distributions of fresh weight and enzyme activity in etiolated maize shoots of various ages. Shoots were produced from untreated seeds under the same conditions as those used for the germination of irradiated material, except for the variation in duration of germination. Mean lengths and weights of the shoots used and distribution of fresh weight in the shoots are shown in table 4 and specific activities are shown in table 5. Although the data were not subjected to analysis of variance, it appears that they are similar to the data from the irradiation experiments with respect to points (a), (b), and the first part of (c) listed in the preceding paragraph. It is interesting to note, however, that shoots which were short by virtue of being young exhibited distribution patterns which differed in certain respects from the patterns observed in shoots which were made short by the effects of
Table 5-Specific activities of 3 enzymes in preparations of etiolated maize shoots of various ages, and of the 3 principal portions of such shoots.

\begin{tabular}{|c|c|c|c|c|c|}
\hline \multirow[t]{2}{*}{ Portion } & \multirow{2}{*}{$\begin{array}{l}\text { Age, } \\
\text { dayss }\end{array}$} & \multirow{2}{*}{$\begin{array}{l}\text { N content } \\
\text { of prep. } \\
\text { (mg. } / \mathrm{ml} \text {.) }\end{array}$} & \multicolumn{3}{|c|}{ Specific activity* } \\
\hline & & & $\begin{array}{c}\text { Aeid } \\
\text { phos- } \\
\text { phatase }\end{array}$ & $\begin{array}{c}\text { Per- } \\
\text { oxi- } \\
\text { dase }\end{array}$ & $\begin{array}{l}\text { Poly- } \\
\text { pheno- } \\
\text { lase }\end{array}$ \\
\hline $\begin{array}{c}\text { Entire } \\
\text { shoot }\end{array}$ & $\begin{array}{l}3 \\
5 \\
6\end{array}$ & $\begin{array}{l}0.088 \\
0.083 \\
0.083\end{array}$ & $\begin{array}{l}1.57 \\
2.44 \\
2.34\end{array}$ & $\begin{array}{l}11 \\
565 \\
59\end{array}$ & $\begin{array}{l}0.14 \\
0.67 \\
1.34\end{array}$ \\
\hline $\begin{array}{l}\text { First } \\
\text { internode }\end{array}$ & $\begin{array}{l}3 \\
5 \\
6\end{array}$ & $\begin{array}{l}0.078 \\
0.053 \\
0.040\end{array}$ & $\begin{array}{l}1.54 \\
2.90 \\
4.24\end{array}$ & $\begin{array}{r}54 \\
105 \\
157\end{array}$ & $\begin{array}{l}0.13 \\
0.44 \\
0.19\end{array}$ \\
\hline Coleoptile & $\begin{array}{l}3 \\
5 \\
6\end{array}$ & $\begin{array}{l}0.080 \\
0.090 \\
0.053\end{array}$ & $\begin{array}{l}1.54 \\
2.02 \\
3.03\end{array}$ & $\begin{array}{l}3.4 \\
28 \\
44\end{array}$ & $\begin{array}{l}0.17 \\
0.36 \\
0.11\end{array}$ \\
\hline Leaves & $\begin{array}{l}3 \\
5 \\
6\end{array}$ & $\begin{array}{l}0.123 \\
0.140 \\
0.095\end{array}$ & $\begin{array}{l}0.69 \\
1.12 \\
1.14\end{array}$ & $\begin{array}{l}12 \\
18 \\
20\end{array}$ & $\begin{array}{l}0.78 \\
5.45 \\
5.17\end{array}$ \\
\hline
\end{tabular}

irradiation. For example, in the age experiment, increasing shoot length (rather than decreasing shoot length as in the irradiation experiments) was associated with decreases in the percentages of fresh weight and phosphatase activity contributed by the first internode and increases in the percentages contributed by the other two portions of the shoot.

Comparison of the specific activities listed in table 5 with those in table 3 furnishes further evidence of altered meta. bolic patterns in shoots from appropriately-irradiated seeds. Thus, where trends of increasing enzyme activity were observed, they were usually associated with decreasing shoot length in the irradiation experiments and with increasing shoot length in the age experiment. Clearly the metabolism of the irradiation-stunted shoots differed from that of the shoots which were short because of their youth.

The relationship of the present results to the primary effects of X-ray and thermal neutron irradiation is not immediately apparent. It is reasonable to assume that a full understanding of the effects of irradiation on the maize plant must await improved knowledge of the normal growth and development of that plant, and that studies such as those of Stafford (6), Lund et al. (4), Hanson et al. (1), and the present work will contribute to the eventual understanding of these matters.

\section{SUMMARY}

Etiolated shoots from control and irradiated maize seeds were dissected into the three major portions, first internode, coleoptile, and unexpanded foliage leaves, and preparations of the three portions were assayed for the activities of acid phosphatase, peroxidase, and polyphenolase. Specific activ. ities of acid phosphatase and peroxidase in the leaf preparations increased significantly with dosage of irradiation; otherwise, no significant irradiation-induced differences in specific activity were observed. Consideration of the contributions of the three shoot portions toward total fresh weight and enzymatic activities indicated that activity dis. tribution patterns of acid phosphatase and peroxidase were altered by the irradiation treatments. The contributions of each shoot portion toward the total activities of acid phosphatase, peroxidase, and polyphenolase were significantly correlated with respective fresh weight contributions of the portions. In the case of polyphenolase a negative correlation coefficient was obtained, while for the other two activities the correlation coefficients were positive. Comparison of results obtained with irradiated material and untreated material of various ages clearly indicates that irradiation- 
stunted shoots differed metabolically from shoots which were short by virtue of being young.

\section{LITERATURE CITED}

1. Hanson, J. B., Hageman, R. H., and Fishir, M. E. The association of carbohydrases with the mitochondria of corn scutellum. Agron. J. 52:49-52. 1960.

2. HAskins, F. A. Changes in the activities of several enzymes during germination and seedling development of corn (Zes mays L.). Plant Physiol. 30:74-78. 1955.
3. - and Chapman, H. W. Effects of irradiation, maleic hydrazide, temperature, and age on enzyme activity in seedlings of corn (Zea mays L.). Physiol. Plant. 9:356-362. 1956.

4. Lund, H. A., Vatter, A. E., and Hanson, J. B. Biochemical and cytological changes accompanying growth and differentiation in the roots of Zea mays. J. Biophys. Biochem. Cytol. $4: 87-98.1958$.

5. SNEDECOR, G. W. Statistical Methods, fifth edition. The Iowit State College Press, Ames, Iowa. 1956.

6. STAFFORD, H. A. The distribution and development of enzymes in pea seedlings. Bull. Torrey Bot. Club 79:351-358. 1952. 